\title{
TRANSPORTATION PLANNING IN SOUTH AFRICA: A FAILURE TO ADJUST
}

\author{
DAVID DEWAR \\ Emeritus Professor, Senior Research Scholar, University of Cape Town, South Africa
}

\begin{abstract}
The structure and form of South African cities has historically been powerfully informed by two main ideologies: the planning ideology of modernism; and the political ideology of apartheid or separate development. The primary urban spatial patterns resulting from these influences acting in combination are low density sprawl, fragmentation and separation. These in turn, impose enormous costs on society. Sprawl rides roughshod over wilderness and rural landscapes at an alarming rate. The system generates enormous amounts of movement (particularly, car-based) at great cost in terms of household budgets, time loss and productivity, air pollution, greenhouse gas emissions, and so on, Moreover, it is the poor who are primarily disadvantaged. In short, urban structure and form are contributing directly to the primary problems of society: poverty; inequality and unemployment. Since 1994, with the attainment of universal franchise, calls for urban restructuring have been high on the South African political agenda. Despite this, there has been little progress in this regard. A primary factor contributing to this has been the failure of the transportation planning profession, which is the most influential of all the disciplines concerned with the South African built environment, to lead significant change. There are several current practices in particular which negatively impact on settlement performance: a continuation of the dominance of car-based travel; the predictive use of demand-based models which reinforce historically-skewed patterns of settlement, as opposed to using transport as an instrument of urban restructuring; an over-emphasis on limited-access routes which create urban barriers; the imposition of technologies on context where preconditions for successful operation do not exist; a failure to integrate different modes of public transportation; a failure to address transport projects holistically: the issue of land value capture; a total lack of concern about spatial quality - the promotion of 'road', not 'street'. These will be discussed in turn. In the final section, a way forward will be suggested.
\end{abstract}

Keywords: spatial planning, modernism, apartheid, car-dominance, limited access routes, skewed demand, imposed technologies, non-integration, spatial quality.

\section{INTRODUCTION}

The structure and form of South African towns and cities has been powerfully informed by two main ideologies: the planning and design ideology of modernism [1], (laced with some ideas from other social movements such as Garden Cities and neighbourhood units) and the political ideology of apartheid or 'separate development' [2], [3].

Spatially, the tenets of the modernist movement accorded well with the requirements of apartheid but apartheid grotesquely distorted these modernist ideas in a number of ways. Firstly, the modernist conception of the desirability of the separation of land uses and urban activities was extended to include compulsory separation on the grounds of race, which the modernist model had never advocated. Secondly, the scale of separation was massively distorted: one-way commutes of over 40 kilometres were, and are, not uncommon around the main cities. Further, it was primarily people of colour who were forced to move to the urban periphery. Because there is a high correlation between race and class in South Africa, it is the poorest people who have furthest to travel. Thirdly, the concept of suburbia, as the image of the good life [4], was extended to subsidised, low-income housing for the urban poor, except that plot and unit sizes were cut to a point where there was very little house and almost no green. Fourthly, the model of the 'neighbourhood unit' [5], or urban village accorded well 
with the imposition of apartheid, in the sense that access to, and egress from these villages, could be relatively easily controlled in the event of social unrest. Finally, the image of the free-standing village in the countryside was perverted into one of pockets of largely mono-functional housing areas cut-off from each other by 'buffer-strips' of open space. Rather than being an asset, these green spaces have become desolate wastelands that are dangerous places in which to be and are dumping grounds for garbage.

The primary spatial patterns that have resulted from these two ideologies acting in combination are sprawl, separation and fragmentation. These have had devastating impacts on the environment and on people. While there are pockets of higher densities, very low densities predominate. On average, gross densities are between 20-30 units per hectare and, in the case of Cape Town, have been steadily decreasing over the last 30 years. Sprawling forms of development have driven roughshod over wilderness and agricultural landscapes at an alarming rate. The system generates enormous amounts of movement at great cost in terms of household budgets, congestion and unproductive time, infrastructural investment, freight inefficiency, air pollution and greenhouse gas emissions. Further the low densities and sprawling forms of development militate against the provision of efficient and viable public transportation and against the emergence of vibrant local markets, which are a pre-condition for small, self-generated enterprises to flourish. This is a factor of great importance in a context of increasing economic globalisation and related increasing structural unemployment. Most of the movement generated is road-based, particularly in private vehicles, which is the worst possible form in terms of greenhouse gas emissions, traffic congestion and movement related mortalities [6]. In short, in a very real sense, settlement structure and form are significantly aggravating the key societal problems of nonsustainability, poverty, inequality and unemployment.

South Africa is not alone in facing problems of sprawl, separation and fragmentation. However, what is not widely recognised is that the problem in South Africa is among the worst in the world. A recent United Nations-Habitat Review of World Cities, (2008) [7], found that South African cities are the most inequitable (and by implication, inefficient) in the world.

Since 1994, with the attainment of a universal franchise, the legal underpinnings of apartheid have been repealed entirely but the dominant spatial patterns have remained and indeed, have worsened. A major reason for this is that the professions concerned with the built environment have failed to adjust and spearhead a major restructuring of urban settlements to make them more efficient, sustainable, equitable and resilient. One of the potentially most important of these professions is that of transportation planning.

\section{THE SPATIAL PLANNING SYSTEM IN SOUTH AFRICA}

Historically, the spatial planning system in South Africa has been part of the problem, not the solution. There are two main dimensions to this. Firstly, the system has been firmly based on the rational-comprehensive model introduced by the modernists. The focus of plans is on land-use and particularly the separation of uses (a focus that, by definition, promotes monofunctionality and sterility). More recently, new legislation The Spatial Planning and Land Management Act (Act 15 of 2013, [8]) has been promulgated which calls for spatial development frameworks (SDF's), not comprehensive plans, to guide spatial growth but, in practice, land-use remains at the centre of the system.

Secondly, spatial planning in almost all local authorities occurs through a system of silos, with different departments making decisions about different elements of public structure (open space, movement of all modes, public institutions, hard urban space, utility services and emergency services) frequently without even consulting with each other: the system is a 
multi-disciplinary, not an inter-disciplinary one. The budgetary process that results is a highly competitive one. In that process, transportation planning and engineering has emerged as a comfortable winner. The structure and form of towns and cities in South Africa is informed more by transport decisions than by any other influence. Indeed, in the City of Cape Town, the urban planning department (which ostensibly is concerned with the performance of the city as a whole) has been incorporated into the transportation department (which is responsible for just one element of public structure), instead of the other way around.

The transportation planning profession in South Africa is strongly based on the North American model: many of the senior transportation planners in the country have been trained at universities in the USA and evidence of the influence of the Highway Code can be seen everywhere despite the fact that many of the dominant transportation practices in South Africa have subsequently been superseded in the USA.

\section{SOME NEGATIVE URBAN TRANSPORTATION PRACTICES}

There are seven practices, in particular, which are impacting negatively on urban performance.

\subsection{A continuation of the dominance of car-based movement systems}

Despite the increasing rhetoric about the importance of, and need for public transportation, the patterns of public expenditure illustrate that decision-makers are committed to expanding and maintaining the road networks and vehicular movement. In part, this is a direct consequence of urban structures that underpin a vicious cycle of increasing lateral spread, pressurising households to purchase a car even though they cannot really afford one, which puts further pressure on road infrastructure.

The cars owned by poorer households are older and are, virtually by definition, low quality. Breakdowns are frequent and petrol consumption is high. The problems which result include increasing gridlock in the larger cities, an increasing loss of productive time, an increasing incidence of traffic accidents and fatalities, increasing air pollution and respiratory illnesses, increasing greenhouse gas emissions, with negative consequences for global warming and climate change and an increasing proportion of household budgets being spent on transport.

\subsection{An over-emphasis on limited access routes}

In the perception of most transport planners in South Africa, there is a direct correlation between improved access and increased mobility. From an urban perspective, however, the terms are very different. 'Mobility' refers to the ease and speed of vehicular movement. 'Accessibility' relates to reducing aggregate amounts of vehicular movement by improving the relationship between places of living and the distribution of urban opportunities particularly work opportunities. Clearly, both are important. Mobility is particularly important for freight movement.

This misunderstanding, however, has led to an over-emphasis on limited access routes in transportation planning in South Africa. This tendency has been reinforced by sources of infrastructural funding. In 1941, the state agreed to fund national inter-city routes, including sections within settlements. The practice soon spread to provincial governments, which built and maintained regionally important routes. Understandably, local (municipal) governments were taken with the idea of other spheres of government funding infrastructure that would otherwise need to be financed with local funds and they eagerly sought to maximise this form 
of additional funding for urban infrastructure. However, a condition of this funding was that the emphasis should be on maintaining fast car mobility, which required limited access routes.

From an urban structural perspective, these limited access routes constitute a serious problem. They represent barriers. Their impact is not unlike building walls across the urban fabric. What happens on one side of this route has nothing to do with what happens on the other: permeability is fractured. Effectively, they divide the urban fabric into a series of 'boxes' or cells. When the boxes are too small, urban integration, which is a political priority, becomes impossible. To illustrate this, the average box size in South African cities is the order of $2 \times 2$ kilometres. By way of comparison, in Shanghai, China, there is approximately $12 \times 7$ kilometres between parallel limited access roadways.

\subsection{Ongoing reinforcement of skewed patterns of demand}

The structure and form of South African towns and cities are severely distorted, largely, but not exclusively, through the implementation of apartheid projects. Rather than transport being seen as a primary instrument of urban restructuring towards more sustainable and socially just spatial patterns, current urban transport practices are reinforcing distortion. To illustrate this, the case of Cape Town can be used.

A feature of Cape Town's movement network, along with other port cities such as eThekwini (Durban), Nelson Mandela Bay (Port Elizabeth) and East London, is that the primary pattern of movement is radial or fan-shaped, focussing on the initial port-based city centre or CBD. As the city has grown, the CBD has become increasingly eccentric in relation to the total urban area, with people having to travel further and further to access it. The consequence has been a vicious cycle of increased road infrastructures to increase capacity, further clogging and further investment. Currently, grid-locks caused by vehicles trying to access the centre are becoming increasingly common: the congestion tipping point has been exceeded. In essence, the problem is structural. As a city with a radial pattern of movement grows, a point is reached where it is necessary to create a more neutral grid-like pattern to take pressure off the centre and to encourage a more polycentric pattern of activities. However, this has not occurred in Cape Town. The issue reflects an even deeper problem. The South African transport planning system is strongly demand-led. It makes extensive use of demand-based models. However, when the underlying structure is distorted, all these approaches can do is to reinforce distortion. The issue of using movement systems to change urban structure and to create new patterns of access is never raised in transport planning circles.

\subsection{The imposition of technologies on contexts where the pre-conditions for successful} operations do not exist

A tendency in the recent past has been for transport planners to attempt to impose transport technologies on contexts where the pre-conditions for the technology to operate successfully do not exist. Cape Town can be used as an example of this. Some years ago, the City of Cape Town decided to explore the possibility of introducing a Bus Rapid Transit System (BRT). Study teams of transport planners and engineers were sent as observers to cities such as Curitiba, Brazil and Bogota, Colombia. They came back as converts to the BRT technology and planning and implementation began immediately. What they failed to explore, however, were the pre-conditions which enabled the technology to work successfully in those contexts. 
Three of these pre-conditions were missing in Cape Town. The first, and arguably, the most important, was sufficient densities: the very low average densities in the city made viable provision impossible.

The second was political acceptance. Historically, the central element of the public transport system has been the Kombi-taxi system. This was never planned: it arose spontaneously as the overland train and bus systems were targeted in the political struggle to make the cities ungovernable, in order to destroy apartheid. It soon became the technology of choice for many poorer households. The taxi owners felt that the introduction of the BRT system would threaten their livelihoods and they opposed it vehemently. As a consequence, the first BRT routes were those serving low density, wealthier, predominantly white areas who seldom use the system. This, too, has undermined viability.

The third factor was city structure. The BRT system was again designed to reinforce the CBD. As a consequence, BRT buses are well patronised only in peak periods. For much of the day, they run largely empty.

Rather than attempting to create the pre-conditions for success before implementing the technology, the city proceeded to implement. The consequence is that the BRT system is currently running at a $75 \%$ loss. The lessons are clear. Technology transfer is complex: if the necessary pre-conditions do not exist, the technology will fail.

\subsection{A lack of integration of public transport modes}

A long-term problem facing the city has been the almost total lack of integration between different transport modes of public transportation. Historically, the overland train and bus systems have competed with each other to meet the needs of the same long-haul commuters. With the expansion of the Kombi-taxi industry in the 1980's and 1990's, taxis competed with the other two for the same passenger base. Later, the taxis organised themselves into umbrella bodies, in part to allocate routes. Frequently, these organisations have been in (frequently violent) conflict with each other. To worsen the situation, the new BRT system being rolled out in some cities is competing for exactly the same routes as the train, bus and Kombi-taxi. The potential role of the rail system, which should represent a great asset, has largely been ignored. Rather than being used, in the first instance, to fill gaps in the rail service, the BRT system has almost entirely ignored the rail network and is establishing networks to compete with it. An integrated transport system requires an interdependent system in which each mode of transport plays the role it is best suited to do. This is far from the case in South African cities.

A key factor underpinning the lack of modal integration is the lack of a co-ordinated, integrated, decision-making structure in relation to transport. Metropolitan governments have no control over rail movement (which is a central government function), bus movement (which is private sector driven) or Kombi-taxis (which are privately owned and driven). The need for an Integrated Transport Authority with control over all modes is urgent.

\subsection{A failure to address transport holistically}

The provision of transportation infrastructure is largely pursued from a narrow engineering perspective, with little consideration given to broader impacts. For example, the instrument of land value capture (based on the understanding that the provision of new movement infrastructures will impact positively on land values on properties abutting it and that some of this windfall should revert to the public purse through higher taxes), which is central to funding new infrastructure in many countries, has never been implemented in South Africa. 


\subsection{A total lack of concern with spatial quality}

Despite the fact that movement routes are one of the largest space users in settlements (commonly 16-20\%) and are certainly the largest form of open space, little thought is given to their spatial quality. Conceptually, the central issue is how to achieve qualities of 'street' (a linear space accommodating many human activities including different modes of movement) as opposed to 'road' (a conduit or 'pipe' for motor cars). Despite the importance of this issue, large movement infrastructural projects are undertaken exclusively by engineers in almost total isolation from the disciplines of urban design or landscape architecture. Qualities of 'road' abound, even in relation to lower order routes in the movement network. This is an important contributor to the environmental sterility which characterises more modern settlements in South Africa.

\section{CONCLUSION}

Restructuring South African towns and cities to make them progressively more efficient, sustainable and equitable is a political imperative in South Africa. This is widely recognised: the issue of restructuring has in fact been prioritised in the recent National Development Plan (2015) [9]. Transportation planning has an important role to play in this for skewed patterns of access underpin a significant part of the urban problem. However, this role cannot be optimised until significant changes are made to a number of current transportation practices. These have been identified here. These changes are not likely to be generated from within the profession. The key lies in ensuring that all major infrastructural projects are implemented by inter-disciplinary (as opposed to multi-disciplinary) teams which include transportation planners but which are led by urban planners and urban designers (the only disciplines which are concerned with the quality and performance of settlements as a totality: all of the others focus on the part, not the whole).

This change, in turn, requires changes to the education system. At present, most postgraduate transportation courses in South Africa are embedded in Civil Engineering departments: the students receive little or no instruction on cities. The practice of working in silos begins here.

Ideally, there should be a core of courses (e.g. natural systems, urban systems, aspects of city design) which are attended by students in all of the Built Environment disciplines (e.g. architecture, urban planning, urban design, transportation planning, civil engineering) to provide a common base from which specialisation can occur [10].

\section{REFERENCES}

[1] Gold, J.R., Creating the Charter of Athens: CIAM and the Functional City, 1933-1943.

[2] Town Planning Review, 69(3), pp. 225-247, 1998.

[3] Dewar, D., A Transformational Path for Cape Town, South Africa, in Wagner, F., Mahayni, R. \& Piller, A.G. (eds), Transforming Distressed Global Communities: Making Inclusive, Safe, Resilient and Sustainable Cities, Ashgate Publishing, Farnham, Surrey, England, pp. 231-244, 2015.

[4] Dewar, D. \& Todeschini, F., South Africa in Pajani, D., Stead, D. (eds), The Urban Transport Crisis in Emerging Economies, Springer Publications: Switzerland, pp. 221246, 2017.

[5] Jacobs, J., The Death and Life of Great American Cities, Jonathan Cape: London, UK, 1962.

[6] Perry, C., Regional Planning Association of New York: Regional Plan for New York State. NY, USA, 1927. 
[7] Academy of Science of South Africa (ASSAF), Towards a Low Carbon City: Focus on eThekwini (Durban), Academy of Science Press: Pretoria, 2011.

[8] United Nations-Habitat, State of the World's Cities Report: Harmonious Cities, United Nations Human Settlement Programme, Earthscan Publishers: London, UK, 2008.

[9] Republic of South Africa, The Spatial and Land Use Management Act (Act 15 of 2013), Government Printer: Pretoria, South Africa, 2015.

[10] National Development Commission of South Africa, The National Development Plan, Government Printer: Pretoria, South Africa, 2015.

[11] Louw, P. \& Dewar, D., Redefining the Curriculum for Spatial Design, Proceedings of the International Competition for Research Papers in Architecture and Urban Design, UIA, Tokyo, 2011. 